\title{
The Infernal Present: Auden's Use of Inferno III in "The Chimeras"
}

James F.G. Weldon

Auden first published "The Chimeras" in TLS on March 9, 1951, and it also appeared later that year in the volume Nones. The poem lightly satirizes modern, urban society with its plurality of human objects which Auden calls the "crowd," and warns the reader against self-destructive involvement with the mythological beasts of the title. Critical response has been slight, and one writer labels the poem "inconsequential."1 A deceptive "ease of surface $^{\prime \prime 2}$ and comic tone, however, mask a complex sociological and metaphysical vision of the contemporary world, a vision intensified by the deliberate and imaginative use of source material. "The Chimeras" recreates the dramatic situation of Canto III of Dante's Inferno, and, although the speaker's (and, by extension, the reader's) identity, the scene, and the literary framework itself remain implicit, the final lines, part amplification and part translation, recall Virgil's counsel to his pilgrim charge, so that the poem not only echoes the classic source, but is a modern reworking of it.

Canto III introduces the Gate of Hell with its terrible inscription, through which Dante passes to the vestibule where he beholds for the first time damned souls in torment. ${ }^{3}$ These are the "trimmers" or "neutrals" - those human spirits and fallen angels who lived "sanza infamia e sanza lodo," "without infamy and without praise" 64) - "who never were alive," who existed without moral commitment and who now occupy the vestibule within the Gate but outside the circles of Hell proper. ${ }^{6}$ Their plight awakens in the naive Dante the natural, human inclination to pity their suffering, until Virgil, explaining the justness of their present condition, warns him against this waste of feeling. Poet and guide then move on. "The Chimeras" duplicates this dramatic situation, for the poem's centre lies not with the chimeras and their victims, as some have conjectured, ${ }^{7}$ but with the unfolding situation itself, in which the reader is finally confronted with a moral dilemma 
admitting no evasion. The bipartite structure sharpens the focus upon this situation and facilitates the process of revelation; the first six stanzas (11. 1-18) describe the 'infernal scene' - the "chimerical condition" of spiritual torment, while the final three stanzas (11. 19-27) shift focus to the reader, the "you," whom the speaker advises to resist damning emotional and spiritual involvement with the unhappy creatures. Auden thus adopts his source's pattern of infernal, potentially piteous scene, followed by guiding counsel, reshaping yet maintaining the original situation.

Allusions, echoes, and quotations link "The Chimeras" to its literary source. The poems's nine stanzas recall the Inferno with its numerological symbolism and structure of nine concentric circles, while the verse pattern approximates Dante's terza rima. ${ }^{8}$ More importantly, the spiritual condition reflected by the chimeras and their victims corresponds to the spiritual non-being of Canto III.

In the first section, ${ }^{9}$ the unnamed speaker introduces the immediate circumstance; certain "telltale signs"10 declare that chimeras have feasted on yet another victim. The speaker then depicts both the chimeras and their victims, who, potentially at least, include both speaker and reader (so the collective pronouns suggest). Identities of scene and character are withheld; only the third stanza reveals a personal rather than impersonal speaker, who still assumes no clearly identifiable role. This together with the density of abstractions and the lack of specific location in time or space renders the "chimerical world" as "unreal" ("Chimeras," 1 . 9) as the fabulous creatures themselves, a world of illusion and fantasy.

Part lion, part goat, and part dragon, the chimeras are hybrid things, "being neither this nor that" ("Chimeras," 1. 7). Throughout his works, Auden never offers a detailed description of the chimeras, nor does he isolate their component parts; the relation and significance of the parts to the whole are purely numerical, and the chimeras, therefore, symbolize Auden's concept of the "crowd," which he defines as follows: "A crowd is composed of $\mathrm{n}$ $>$ I members whose only relation is arithmetical; they can only be counted ... its existence is chimerical."11 Chimeras inhabit a chimerical world, which is not only one of illusion where the unreal masks itself as the real, but a world which is fundamentally infernal: "In the chimerical case of a society embodying a crowd, there would be a state of total unfreedom and disorder; the traditional term for this chimerical state is Hell."12 The presence of chimeras, then, immediately signifies the locality of Hell, an association made explicit in Memorial for the City, where the "pallid affected 
heroes" carry their "hectic quest for the prelapsarian man" beyond the limits of the Glittering City: "Guided by hated parental shades, / They invaded the hell of her natural self. / Chimeras mauled them. ..."13 The mythological, illusive world becomes the infernal world, and it is to such a setting that the speaker introduces us in "The Chimeras."

The victims and the chimeras are specifically the non-beings of Canto III, whose natures Auden modifies to suit the twentieth century; their characteristics include negations of being and consciousness delivered with anaphoric stress:

Absence of heart - as in public buildings,

Absence of mind - as in public speeches,

Absence of worth - as in goods intended for the public, ...

Indescribable - being neither this nor that,

Uncountable - being any number,

Unreal - being anything but what they are, . . .

("Chimeras," 11. 1-3, 7-9)

Auden here refers to a particular kind of crowd called the "public,"14 (as the repetitions above suggest), which differs from other kinds in that it possesses no.external features; the victims become parts of a monstrous, self-destructive whole, for the description of which Auden cites Kierkegaard:

... no single person who belongs to the public makes a real commitment; for some hours of the day, perhaps, he belongs to the public - at moments when he is nothing else, since when he really is what he is, he does not form part of the public. Made up of individuals at the moments when they are nothing, a public is a kind of gigantic something, an abstract and deserted void which is everything and nothing. ${ }^{15}$

Auden's concept of the public combines ideas from modern sociology and existentialism; membership in the social group automatically follows negation of self, or, in other terms, the wilful surrender of individual consciousness, and Auden makes it absolutely clear that such acquiescence of mind constitutes a voluntary abuse of freedom:

Today a man has only two choices; he can be consciously passive or consciously active. He can accept deliberately or reject deliberately, but he must decide. . . . To be unconscious is to be neither an individual nor a person, but a mathematical integer in something called the Public which has no real existence. ${ }^{16}$ 
As Kierkegaard claims and Auden frequently reasserts, the public lacks consciousness and being, and is in the existential sense "unreal." 17 The public also lacks concrete expression, differing from the crowd proper and its extension, the mob, and in this sense, too, it is "unreal," because it has no visible appearance or substance. ${ }^{18}$ At the same time, the public mirrors a social reality; it is all too real, for both the concept and the thing itself are peculiar to the modern world, and were, Auden claims, unknown to the ancient world:

The growth in size of societies and the development of mass media of communication have created a social phenomenon which was unknown to the ancient world, that peculiar kind of crowd which Kierkegaard calls The Public. . . . ${ }^{19}$

The non-being of the chimeras and their victims is, like the world they inhabit, paradoxically both real and unreal, and the confused potential victim (the reader), knowing these non-beings to be "unreal - being anything but what they are" ("Chimeras," 1. 9), nevertheless endangers his own existence should he attempt "to prove they cannot be" ("Chimeras," 1. 12). ${ }^{20}$

Auden's sociological and philosophical colouring of the chimerical world serves not only to clarify but to substantiate that world by linking it solidly to the historical world of contemporary experience, which, in turn, ironically reproduces Dante's Inferno; suggestive of the matter and the method of the Commedia, the vision of experience becomes a vision of hell. ${ }^{21}$ If the presence of chimeras signifies hell in Auden's framework, so does the chimerical condition of unconsciousness, non-being, and lack of identity, all of which equally describe the public. In New Year Letter, Auden writes: "Hell is the being of the lie / That we become if we deny / The laws of consciousness," 22 and the devil, in "Song of the Devil," chants to the non-beings who comprise the damned:

\footnotetext{
"So let each while you may think you're more O.K., More yourself than anyone else,

Till you find that you're hooked, your goose is cooked,

And you're only a cypher of Hell's.

Believe while you can that I'm proud of you, Enjoy your dream:

I'm so bored with the whole fucking crowd of you I could scream!"23
}

The devil describes Hell in the familiar terms of crowds, faceless cyphers, and non-being - a state poignantly expressed by the 
devil's own boredom with his banal, egocentric followers. Dante's spirits of Canto III similarly lack being and identity. Significantly, Dante sees a "crowd" of damned souls, all of whom never truly lived:

$\mathrm{E}$ io, che riguardai, vidi una insegna che girando correva tanto ratta, che d'ogni posa mi parea indegna;

e dietro le venía sí lunga tratta di gente, ch'io non averei creduto che morte tanta n'avesse disfatta.

Questi sciaurati, che mai non fur vivi, erano ignudi. ...

I, who looked, beheld a banner all a-strain, Which moved, and, as it moved, so quickly spun That never a respite it appeared to deign.

And after it I saw so many run, I had not believed, they seemed so numberless, That Death so great a legion had undone.

These paltry, who never were alive, were bare As to the body. ... (ll. 52-57, 64-65)

Unlike Dante's Inferno, Auden's has no historical figures, but his use of language, together with the modern context into which he fits the chimerical world, firmly relates hell to the historical world nevertheless. Because urban, industrialized society is so "aggressively ugly and emphatically banal," ${ }^{24}$ manifestations of qualities such as ugliness and banality are not properly abstractions; the phrase "public building," therefore, is "still a concrete description" 25 of a modern phenomenon, and the "public buildings" of "The Chimeras" (1. 1) create a sense of historicity. Our historical world again emerges in the clichés Auden uses to indicate the presence of chimeras - trite, popular expressions, such as "telltale signs" (1. 4), "ugly customers" (1. 10), and "gobble us up" (l. 18). ${ }^{26}$ Such banal language reflects the mindless slang of the modern public, and is itself an expression of non-being and chimerical illusion: ${ }^{27}$

The human person is a unique singular, analogous to all other persons, but identical with none. Banality is an illusion of identity for, when people describe their experiences in clichés, it is impossible to distinguish the experience of one from the experience of another. The cliché user is comic because the illusion of being identical with others is created by his own choice. ... the banal man thinks of himself as being everybody else, that is to say, nobody in particular. ${ }^{28}$ 
Thus in "The Chimeras" the non-beings immediately lose the most important sign of their identity - their names: "of him, poor foolish fellow, / Not a scrap is left, not even his name" (ll. 5-6). This last line echoes Canto III, where Dante, while recognizing several individuals among the "crowd" of neutrals, contemptuously refuses to name them. ${ }^{29}$ Of them Virgil also says: "Fama di loro il mondo esser non lassa" - "Report of them the world permitteth none" (1. 49).

The poem's second section reveals the dramatic situation, which the first had only intimated through echo and allusion. The final three stanzas essentially translate Virgil's counsel to Dante: "non ragioniam di lor, ma guarda e passa" (1. 51), ${ }^{30}$ which Binyon renders, "Let us not talk of them. Look and pass on." ${ }^{11}$ The verb "ragionare," however, has several meanings, most of which suggest effort of mind, not the mere uttering of words or choice of subject: "usare la ragione, riflettere, argomentare in base alla logica, pensando o parlando," "trattare, discutere di un argomento," and "giudicare, calcolare. ${ }^{\prime 32}$ Although the translations "to talk over" and "to talk about" are literally correct, ${ }^{33}$ the verb frequently implies mental effort, and the immediate context suggests that it does so here. In Canto III, Dante's initial reaction to the scene of tormented neutrals is to feel pity ${ }^{34}$ :

Quivi sospiri, pianti e alti guai risonavan per l'aere sanza stelle, per ch'io al cominciar ne lagrimai.

Here lamentation, groans, and wailings deep

Reverberated through the starless air,

So that it made me at the beginning weep. (11. 22-24)

Throughout his journey in Hell, Dante several times confronts this dilemma, where, upon witnessing human spirits afflicted with torment, an inner conflict arises between the feeling that justice is vindicated and a natural feeling of pity. ${ }^{35}$ When Virgil, having "vindicated" justice by explaining the nature of the spiritual condition so afflicted, speaks to Dante, he not only tries to enlighten him but to set his mind at rest, for Dante has been deeply disturbed by the vortex of cries and lamentations swirling about him. The disturbance, moreover, accompanies the pity Dante naturally feels for these suffering beings, and the verb ragionare in this context expresses agitation of mind resulting from Dante's attempt to reconcile justice and pity. ${ }^{36}$ Virgil, then, in effect says, "Let us not perplex our minds on their account (they are not 
worth the effort). Look and pass on." ${ }^{37}$ Considered in this light, Virgil's counsel discourages both concern and pity for the nonbeings of Canto III, and Auden's rendering of line 51 therefore combines translation and interpretation; the material interspersed simply amplifies the immediate context of the Inferno to include the chimerical world (I place Auden's translation in italics):

If someone, being chaste, brave, humble,

Get by them safely, he is still in danger,

With pity remembering what once they were,

Of turning back to help them. Don't.

What they were once was what they would not be;

Not liking what they are not is what now they are.

No one can help them; walk on, keep on walking,

And do not let your goodness self-deceive you:

It is good that they are but not that they are thus. ${ }^{38}$

These final lines contain the crux of the poem. Auden's expanded translation directly appeals to Canto III and the framework of the Commedia, thereby identifying both characters and setting. The unnamed speaker now emerges as a modern Virgil, and the reader, by implication, becomes a modern Dante journeying through the dolorous regions of the underworld. Moreover, here for the first time the speaker points to the idea of a "journey," in which the traveller is faced with the moral choice of remaining in the infernal world or of "walking on," presumeably towards a new Eden. The phrases "turning back" and "walk on, keep on walking" remind us of the larger framework of journey, pilgrimage, and quest, and locate the poem as a momentary stop in our travel through the Inferno, where we glimpse at tormented souls whom we now recognize, like Dante, as our historical contemporaries. Canto III acts not as a plausible analogy, but as a positive identity for the world of "The Chimeras."

Like The Sea and the Mirror, "The Chimeras" is a dramatic poem which recreates culturally significant literary material ${ }^{39}$ and which expresses in poetic concentration ideas repeatedly contemplated by Auden during the latter part of his life. He achieves a new kind of dramatic intensity here, for the overtly recognizeable features of the informing source are deliberately witheld until the poem's climactic final section, and yet he omits mention of Dante, Virgil, or the Commedia. At the same time, he deliberately invites comparison with Canto III by means of echo, allusion, and simi- 
larity of theme - the spiritual condition of non-being. The most powerful touch, however, unleashes the full force of comic vision $^{40}$ as source, situation, and language converge to confront the reader with the terrible realization that the familiar world of crowds, public buildings, and popular speech is none other than Hell. "The Chimeras" functions as the Canto III of a modern Inferno, and Auden's reluctance to reveal either source or situation perhaps further suggests that a world so lacking identity, a world of indefinite landscapes and unnamed travellers, lies beyond redemption and beyond hope.

\section{Università di Cagliari}

\section{NOTES}

1 Justin Replogle, Auden's Poetry (London: Methuen, 1969), p. 162.

2 G.S. Fraser, "The Cheerful Eschatologist" (a review of Nones), The New Statesman and Nation, 43 n.s. (March 1, 1952), 249, coins this appropriate phrase to describe Auden's predominant new style in Nones.

3 Auden was to some extent preoccupied with Dante and with Canto III throughout his poetic career. In "Criticism in a Mass Society," The Intent of the Critic, ed. Donald A. Stauffer (Princeton: Princeton Univ. Press, 1941), p. 132, he wrote, "The three greatest influences on my own work have been, I think, Dante, Langland, and Pope." Carlo Izzo, Auden's Italian translator, claims in "The Poetry of W.H. Auden," Auden: A Collection of Critical Essays, Twentieth Century Views, ed. Monroe K. Spears (Englewood Cliffs: Prentice-Hall, 1964), p. 127 , that in an interview in Venice, Auden confessed to a "devotion to Dante, whom he reads and rereads in the original." According to Charles Osborne, W.H. Auden: The Life of a Poet (New York \& London: Harcourt Brace Jovanovich, $1979)$, pp. 228-47, Auden spent the summers of the late forties and fifties on Ischia, a small island off Naples, and acquired a competent familiarity with the Italian language and customs; in "The Essence of Dante," New York Times, June 29,1947 , section 7, pp. 4, 23, he again announces his preference for Dante in the original and demonstrates a knowledge of that poet's works in Italian.

His earliest poetry reflects interest in Canto III; the poem "Suppose they met, the inevitable procedure" contains the following passage:

In these, who saw and never rubbed an eye . . .

It was no wonder they were not impressed

By certain curious carvings on the porch,

A generous designation of the fate

Of those shut altogether from salvation.

Down they fell. Sorrow had they after that.

Joseph Warren Beach, The Making of the Auden Canon (Minneapolis: Univ. of Minnesota Press, 1957), p. 282, notices the allusion above to the inscription over Dante's Gate, but believes that the poem first appeared in the volume Poems (1930), from which it was subsequently dropped in the revised edition of 1933. In The English Auden: Poems, Essays, and Dramatic Writings, 1927-1939 (New York: Random House, 1977), editor Edward Mendelson includes the poem, numbered "IV," and indicates the date of composition, September, 1927, but 
does not refer to the date of publication. However, the poem first appeared in Stephen Spender's edition, Poems (1928), from which the lines above were cited, which was hand-printed only in part by Spender, the rest having been finished and bound by Holywell Press in Oxford (see Osborne, The Life of $a$ Poet, p. 57). Spender's printing consisted of "about 45 copies" which were circulated among Auden's friends at Oxford. The version appearing in Mendelson's edition of the early poems is one of Auden's revisions, and has, for example, several alterations such as the line "Sorrow they had after that" and the phrase "in the porch."

4 Dante Alighieri, La Divina Commedia, ed. Natalino Sapegno, Scrittori Italiani, 3 vols., I (1955; rpt. Firenze: "La Nuova Italia," 1964), Inf. III, 1. 36; all further references will be to the text of this edition. Also consulted was Dante Alighieri: La Divina Commedia, ed. Giuseppe Campi, 4 vols. (Torino: Unione TipograficoEditrice Torinese, 1915), which contains the variants of the various manuscripts.

5 Dante, The Divine Comedy, Dante: The Selected Works, ed. Paolo Milano, trans. Laurence Binyon (1947; rpt. London: Chatto \& Windus, 1972), Inf. III, 1. 36. This text was originally published by Viking Press and titled The Portable Dante, which Auden reviewed in "The Essence of Dante"; there he stated, "Lawrence (sic) Binyon's translation . . . seems to me indubitably the best so far" (p. 4). I use this translation throughout.

6 References to Canto III and to the spiritual condition there embodied permeate Auden's work before and after composition of "The Chimeras" (see also note 3 above). George W. Bahlke, The Later Auden: From "New Year Letter" to About the House (Rutgers Univ. Press, 1970), pp. 114-15, identifies the spiritual condition to which Caliban assigns modern man in Caliban to the Audience as essentially that of Canto III; here on the "journey of life," man occupies an infernal landscape, which corresponds to his spiritual malady of non-being, and we are told that "no decision will ever alter the secular stagnation" (Caliban, The Sea and the Mirror, For the Time Being [London: Faber \& Faber, 1945], p. 51). In Nones (London: Faber \& Faber, 1952), pp. 43-44, Auden placed "The Chimeras" after Cattivo Tempo" with its "minor devils" of creative insipidness:

Nibbar, demon
Of ga-ga and bêtise,
Tubervillus, demon

Tubervillus, demon

Later, in the Collected Shorter Poems, 1927-1957 (1966; rpt. New York: Vintage Books, 1975), "The Chimeras" precedes "Merax \& Mullin" with its "one devil in the lexicon / Who waits for those who would unwish themselves" (11. 1-2) and "Limbo Culture" whose tribesmen lack words in their vocabulary "you could translate by Yes or No, / Nor do its pronouns distinguish between Persons" (1l. 11-12). Apparently deceived by the title, John Fuller, A Reader's Guide to W.H. Auden (London: Thames \& Hudson, 1970), p. 233, connects "Limbo Culture" with Dante's 'Limbo' of Inferno IV, but the moral vacillation of the Limbo population firmly places them among the spirits of Canto III, who could consent neither to rebel with Satan nor to remain loyal to God (11. 38-39). All four short poems treat an infernal world of non-being analogous to that of Canto III, and their proximity at various phases of publication seems to stem from a common subject and source.

7 Thus Fuller, A Reader's Guide, p. 232, sees the poem as an allegory in which the chimeras personify "any of those illusions that we have about life which ignore the truth of the individual." Herbert Greenberg, Quest for the Necessary: W.H. Auden and the Dilemma of Divided Consciousness (Cambridge, Mass.: Harvard Univ. Press, 1968), pp. 177-78, does not analyze the whole poem, but he, too, isolates the chimeras, ignores the context, and discovers, essentially, an allegory. 
8 Auden here uses a kind of accentual or blank verse version of Dante's terza rima as the foundation of his stanza form. The "balanced" stanzas (stanzas 1, 3, and 5) seem to have been suggested by verse constructions such as 11 . 25-27 of Canto III.

9 The tight organization of this section illustrates its structural integrity. The section consists of three stanza-pairs in each of which a "loose" stanza follows a formally "balanced" one; both together form a single sentence. By contrast, the second section has no "balanced" stanzas.

10 W.H. Auden, "The Chimeras," Collected Shorter Poems, 1. 4. This version is substantially identical to the text published in Nones, and represents Auden's final version.

11 Auden, "The Virgin \& the Dynamo," The Dyer's Hand and Other Essays (1962; rpt. New York: Vintage Books, 1968), p. 63.

12 Ibid., p. 64. Auden distinguishes the "crowd" from the "society" and the "community." A society loves itself and subordinates the self-love of its members, whereas the members of a community are united by a "common love of something other than themselves" (p. 64); a crowd, on the other hand, "loves neither itself nor anything other than itself" (p. 63). A crowd, then, generates neither collective self-love nor collective selfless-love, and its members, subordinating their self-love to nothing or no one, wallow in indulgent, anarchic selfregard. Like the tormented spirits of Canto III, they choose neither good nor evil, "ma per sé foro" - on themselves intent" (1. 39).

13 Memorial for the City, Collected Shorter Poems, p. 291; interestingly, this poem was published along with "The Chimeras" in the volume Nones. Here, too, the vision of a hell inhabited by chimeras alludes to Dante's Inferno and the vacillating spirits of Canto III; we are told that the "pallid affected heroes" changed "their Beatrices often" (p. 291).

14 Greenberg, Quest for the Necessary, p. 178 correctly identifies the chimeras as a metaphor for the Kierkegaardian public, but overlooks the relation of the victims to the chimeras and the metaphysical background. To be consumed by a chimera involves the transformation of the victim, who then becomes an unspecified part of the 'whole'; thus the reader risks his own identity "with pity remembering what once they were" ("Chimeras," 1. 21), where "they" refers to the monstrous chimeras now changed from what they were - victims, "real" human beings now transformed to non-beings. The victim-chimeras are, therefore, "nothings," that is, faint shadows of their former selves, a condition for which they are entirely responsible: "What they were once was what they would not be; / Not liking what they are not is what they now are" ("Chimeras," 11. 23-24). Passages describing the chimerical condition (monsters and victims) obliquely point to the idea of being through the frequent use of the various forms of the verb "to be."

15 Auden, "The Poet \& the City," The Dyer's Hand, pp. 81-82.

16 Auden, "Criticism in a Mass Society," p. 134. Although Auden does not develop systematically a philosophy of society, his numerous references to the 'public,' both in prose and poetry, maintain coherence and consistency. He depicts membership in the public, for example, in much the same terms of conscious transgression in "Soren Kierkegaard," Forewords and Afterwords by W.H. Auden, ed. Edward Mendelson (New York: Vintage Books, 1974):

The multitude of ordinary men and women . . . cannot lose the sense that they are individuals; they can only try to drown that sense by merging themselves into an abstraction, the crowd, the public ruled by fashion. (pp. 179-80)

17 The chimerical world confuses or identifies "faces" and "masks." Human beings have (or should have) faces, external expressions of 'real' being; faces, therefore, belong to unique individuals, and, Auden asserts, "a real face expresses a responsibility for itself" ("The Virgin \& the Dynamo," p. 62). The op- 
posite of a face, a mask, expresses the evasion of responsibility and the negation of being. Members of crowds are referred to as "faceless cypers" ("The Virgin \& the Dynamo," p. 63) or "the faceless many" ("Nones," Horae Canonicae, Collected Shorter Poems, p. 330); "Nones" and "Prime" were published in the volume Nones, and were included in the completed sequence Horae Canonicae, appearing later in The Shield of Achilles (New York: Random House, 1955).

18 In "The Poet \& the City," Auden argues (implicitly) that the public actually exists, but not through the concrete. Among members of the public, there is no contact, and unlike the crowd or the mob, the public is not "a visible congregation of a large number of human individuals in a limited physical space" ( $p$. 82). Auden uses the word "crowd" in a specific and in a general sense. The general term "crowd" (for the definition of which see page 4 above) includes the specific term "crowd" (a "visible congregation"), the "mob" (an emotionally inflamed "visible congregation"), and the "public." The public can include several minor 'publics' (hence the plural "chimeras") and can occasionally embody itself in a "visible congregation":

... in the crowd, for example, which collects to watch the wrecking gang demolish the old family mansion, fascinated by yet another proof that physical force is the Prince of this world against whom no love of the heart shall prevail. (p. 83)

19 Auden, "The Poet \& the City," p. 81.

20 Therefore, Greenberg, Quest for the Necessary, oversimplifies the ontological and moral dilemma posed by "The Chimeras"; the public presents a more complicated and serious threat than "a dragon who uses our own strength to destroy us when we make the mistake of believing in its reality" (p. 178 - italics mine). As line 12 indicates, to deny the reality of the chimeras is equally destructive.

21 Northrop Frye admirably discusses the significance of Dante's Canto III for modern poets in T.S. Eliot, Writers and Critics (Edinburgh \& London: Oliver \& Boyd, 1963), pp. 50-54, and he might well have included Auden along with Eliot and Baudelaire. For Auden, the historical world is a fallen world, and he describes it in terms which recall his definition of the infernal chimerical world (see page 6 above):

The historical world is a fallen world, i.e., though it is good that it exists, the way in which it exists is evil, being full of unfreedom and disorder ("The Virgin \& the Dynamo . . . ." p. 70)

Notice also the correspondence between this passage and the final line of "The Chimeras."

22 Auden, New Year Letter, Collected Longer Poems, p. 107.

23 Auden, "Song of the Devil," City Without Walls and Other Poems (London: Faber \& Faber, 1969), p. 49.

24 Auden, "Postscript: Christianity \& Art," The Dyer's Hand, p. 460.

25 Auden, "Notes on the Comic," The Dyer's Hand, p. 382. (London: Faber \& Faber, 1969), p. 49.

26 I maintain Monroe K. Spears' distinction in The Poetry of W.H. Auden: the Disenchanted Island (New York: Oxford Univ. Press, 1963), pp. 24, 34-35, between Auden's "popular" and "colloquial" styles. The popular style has the trite, flat language of popular songs, while the colloquial style involves civilized, but colloquial, conversational language. In "The Chimeras," style supports structure, for although the colloquial style permeates the whole poem, the popular style characterizes the first section only, stylistically separating the first six stanzas from the rest.

27 The devil in "Song of the Devil" also equates banal language with the infernal, historical world: "I've tried / To clothe my fiction in up-to-date diction, / The contemporary jargon of Pride." 
28 Auden, "Notes on the Comic," p. 379.

29 John D. Sinclair, trans. and ed., The Divine Comedy of Dante Alighieri, 3 vols., I (1939; rpt. New York: Oxford Univ. Press, 1970), pp. 54-55. Dante, while refusing to name any spirits nevertheless clearly recognizes the one "who made the great refusal in cowardice" (1. 60). This is Pope Celestine V, who abnegated the papal throne in favour of Boniface VIII, one of Dante's chief enemies (see Charles S. Singleton, trans. and ed., Dante Alighieri: The Divine Comedy, Bollingen Series LXXX, 3 vols., I, Part 2 [Princeton Univ. Press, 1970], pp. 47-52).

30 I am indebted to Mariana Costa and Bruno Conti for ingraining this line in my memory, enabling me to recognize it in Auden's poem.

31 John Aitken Carlyle, trans., The Divine Comedy of Dante Alighieri, eds. C.H. Grandgent and Ernest Wilkins, Modern Library (1932; rpt. New York: Random House, 1950), p. 23, Sinclair (p. 49), and Singleton (I, Part 1, p. 27) similarly translate the verb.

32 Dizionario Garzanti della Lingua Italiana (Milano: Garzanti, 1965).

33 See Dizionario Garzanti: Italiano-Inglese/Inglese-Italiano (Milano: Garzanti, 1968), Grande Dizionario: Inglese-Italiano/Italiano-Inglese, ed. Mario Hazon (1961; rpt. Milano: Garzanti, 1967), and Dizionario delle Lingue Italiano e Inglese, ed. Vladimiro Macchi, I Grandi Dizionari Sansoni, 4 vols. (Firenze e Roma: Sansoni, 1970).

34 G.A. Borgese, "The Wrath of Dante," Essays on Dante, ed. Mark Musa (Bloomington: Indiana Univ. Press, 1964), pp. 96-97, calls cantos I-VII of the Inferno the "cantos of pity" because Dante here is overwhelmed by this feeling, which he strives to counteract in succeeding cantos.

35 Edward Moore, Studies in Dante, Second Series (1899; rpt. Oxford Univ. Press, 1968), pp. 212-13.

36 Pity, Auden thought, was one of our civilization's greatest evils (Osborne, The Life of a Poet, p. 59). Christopher Isherwood, in Lions and Shadows: An Education in the Twenties (London: Hogarth Press, 1938), p. 301, [Osborne's source] represents the ideas of Weston (Auden) as taught by Barnard (John Layard) as follows:

Pity, consciously induced, loveless and sterile, is never a healer, always a destroyer. ... If you find yourself beginning to pity anyone who is ill or in trouble... you cannot help him: you had far better abandon him altogether.

In a similar vein, Auden says in "Hic et Ille," The Dyer's Hand, p. 98-99:

Rejoice with those that do rejoice. Certainly. But weep with them that weep? What good does that do? It is the decent side of us, not our hardness of heart, that is bored and embarrassed at having to listen to others because, as a rule, we can do nothing to alleviate them. To be curious about suffering which we cannot alleviate - and the sufferings of the dead are all beyond our aid - is Schadenfreude and nothing else.

Auden frequently worked out his ideas for poetry in prose, and the quotation above serves as a useful commentary upon "The Chimeras."

37 Virgil's use of the collective verbal form is provocative; did he, too, incline towards pitying the suffering spirits? Virgil's collective pronoun (implicit in the verb) perhaps accounts for Auden's use of collective pronouns in "The Chimeras."

38 Thus Auden in "Do You Know Too Much," Esquire (December, 1962), 270:

Though it is good that everything exists, the way in which a particular thing exists may be evil or, at least, not as good as it could be,

or, again, in "The Virgin \& the Dynamo," p. 70:

The historical world is a fallen world, i.e., though it is good that it exists, the way in which it exists is evil. 
39 Barbara Everett, Auden, Writers and Critics (Edinburg \& London: Oliver \& Boyd, 1964), pp. 75-85.

40 Auden claims, "What no critic seems to see in my work are its comic undertones. Only through comedy can one be serious" (quoted in The Life of a Poet, p. 332). 